\title{
THE BACKGROUND AND TECHNIQUES OF EQUITY AND BANKRUPTCY RAILROAD REORGANIZATIONS-A SURVEY
}

\author{
WARNER FULLER *
}

The complete story of the financial travail of American railroads and of the legal devices and business expedients resorted to in an attempt to resolve their difficulties is a history which is all too long to allow presentation in any but the most general way within the limits of a short article. The high-spots, however, can be touched upon.

The financial problems which faced the railroads of this country in the period of the:r infancy, ${ }^{1}$ that is to say, in the era preceding 1850 , were comparatively simple and easy of solution. During this time financing was usually accomplished by the sale of capital stock, rarely by the corporate mortgage. Under-estimation of the cost of the project was the chief source of financial difficulty. When funds ran out, the entrepreneurs put up or raised more money, issued additional stock, and carried the construction to completion. It was with the advent of the corporate mortgage in railroad financing in the era following $185^{\circ}$ that the law and technique of corporate reorganization in the United States had its real beginning.

In this period the mortgage was used with an increasingly lavish hand. The result was that railroad financial troubles and the railroad mortgage became indissolubly associated as the Siamese twins. It was thought that railroad revenues would constantly increase with the development of the country, and that therefore relatively heavy fixed charges could be sustained. In many cases, however, revenues did not show the anticipated increase and the top-heavy mortgage set-up and inadequate revenues forced many carriers to default on their mortgages. Financial misfortunes of this type were especially prevalent in the times of severe economic stringency when there was an inevitable shrinkage in railroad revenues. As a result of such defaults the property securing the mortgage could be sold at foreclosure, or where the mortgage so provided, it might be taken over and operated by the mortgage trustee for the benefit of the bondholders. But in the period between $185^{\circ}$ and the

- B.S., 1924, University of Oregon; LL.B., 1927, Yale University. Member of the California and Oregon Bars. Professor of Law, Washington University School of Law. Consultant to the Federal Coordinator of Transportation in the drafting of the 1935 amendments to Section 77 of the Bankruptey Act. Author (with Leslie Craven) of The 1935 Amendments of the Railroad Bankruptcy Act (1936) 49 HArv. L. Rev. 1254, and of other articles in legal periodicals.

${ }^{2}$ For 2 brief treatment of the early history of railroad financing, see Defing, Finascinz Pouscr or Corporattons (3d ed., 1934) bk. Vi, c III. 
Fanic of 1873 , resort to either of these alternatives was not frequent. Usually a settlement was arranged between the debtor and the security-holders under which overdue interest was funded. This course of action was dictated largely by technical deficiencies in, and one-sided provisions of, railroad mortgages then in use.2 The funding expedient, of course, afforded merely temporary relief and made the underlying financial situation of the debtor all the more critical, because no permanent adjustments between income and outgo had been effected. The day of reckoning was merely postponed. Later insolvencies were almost invariably the consequence.

The foundation for the modern equity reorganization technique was laid in the period following 1850.3 This technique, as it was ultimately developed, involved foreclosure and sale of the insolvent carrier's property to a new company formed to take it over. The equity receivership was an essential ingredient of this process. It may be explained that an equity receiver is a disinterested person who, according to the usual definition, has been appointed by a court to hold or manage property which is subject to a pending' suit until the rights to the property have been judicially determined." While the property remains in the control of the receiver, it cannot, save in unusual circumstances, be affected by other courts or persons.

After it became established that receivers might be appointed to take over the operation of railroads, resort to the use of the receivership was most common in connection with foreclosure proceedings instituted on behalf of the holders of defaulted railroad bonds. ${ }^{5}$ From the bondholders' point of view, the appointment of a receiver in connection with such proceedings had the advantage of taking the mortgaged property from the possession of the debtor's management and permitting revenues of the property to be applied on their obligations pending sale or foreclosure. Although the mortgage foreclosure receivership was useful in some situations, it by no means solved the bondholders' problems. This type of receivership extended only to the property subject to the mortgage, which frequently was only a part of the debtor's system. Since a railroad must be operated as a unit, this limitation greatly reduced the utility of the foreclosure receivership. Where the railroad had a complex aggregate of mortgages, legal machinery was needed which would extend the receivership to the entire system of the debtor and permit its centralized operation pending the development of a plan of reorganization. Not only the bondholders but also the railroad management felt this need. But it was not until 1884 that the wellknown Wabash receivership pointed the way to such a possibility.

By 1884 , when the Wabash reorganization was instituted, it had become well established that an equity receiver might be appointed, subject to certain limitations, in connection with pending litigation against a railroad, where the application was made on behalf of the debtor's creditors or stockholders. ${ }^{6}$ Defying precedent, the

'Crowell, Railway Receivership in the United States (1898) 7 Yal. Rev. 319, 326.

22 CLARK, ReCEIVERs (2d ed., 1929) 1249. 'I CLARR, op. cit. supra note 3, at 15.

srior to 1850, it was not clear that receivers could be appointed to take over railroad operation. Id. 2t 1249 .

- This requirement of pending litigation was met, for example, where foreclosure of a defnulted mortgage was sought. Foreclosure constituted a pending suit brought by corforate creditors against the debtor. 
Wabash Company itself filed a bill in equity, which had no connection with any pending suit, in which it requested the appointment of a receiver for its entire property. ${ }^{7}$ The object of the bill was to place the Wabash properties in the lap of the court until a reorganization could be accomplished. The bill alleged, among other things, that the petitioner was insolvent and that unless a receiver was appointed, suits would be brought against it and its properties disintegrated, with great resulting loss to creditors, stockholders, and the general public. The bill was sustained and influenced reorganization profoundly, but certain doubts which were cast upon its soundness, and the fact that the procedure there followed lacked a wellformulated basis for effecting the reorganization once the receivership had been commenced, led to an ultimate departure from this technique.8 The reorganization technique, as it was finally evolved following the Wabash case, was transformed from one in which the company itself formally instituted receivership proceedings in its own name to one in which a friendly creditor of the company was induced to commence the receivership proceedings, ostensibly for himself but actually at the instigation of the debtor.

\section{Institution of Equity Reorganization Receiverships under the Modern Technique}

After a debtor's management had reached the decision that reorganization was necessary, attorneys for the company drew up all necessary legal papers in great secrecy, in order to prevent creditors from anticipating the receivership and subjecting important property to their claims or from instituting unfriendly receivership proceedings in the state courts. ${ }^{10}$ Then a friendly creditor of the company was sought who was willing to file a petition requesting the appointment of a receiver for the debtor. In order that statutes governing the institution of suits in the federal courts might be complied with; it was necessary for him to reside in a state other than that of the incorporation of the debtor, and to have a claim exceeding $\$ 3,000$. $^{11}$ The federal courts have been preferred for railroad reorganizations for the reason, among others, that the systems of the insolvent carriers frequently extend into several states, and if the state courts were used, separate receivership proceedings would have to be commenced in each state in which the railroad's properties lay. While it is also true that separate proceedings, called ancillary proceedings, must be instituted in each federal judicial district through which the debtor's system runs, the intimacy existing between the various federal district courts is much greater than between state courts, and the federal courts of the ancillary proceedings usually allow the

\footnotetext{
'For a more detailed discussion of the receivership background of the Wabash reorganization, see Chamberlain, New-Fashioned Reccivership (1896) ro Haxv. L. REv. 139.

- See Byrne, The Foreclosure of Railroad Mortgages in the United States Courts in Some Legat. Panses of Corporate Financing, Reorganization and Regulation (1917) 77, 86 et seg.

- A generalized description of the equiry reorganization process is here set forth. Individual variations from certain aspects of the process may be found. For a more detailed and technical discassion of the manner of instituting railroad receivership proceedings, see id. at 77 et seq.

${ }^{10}$ Although the past tense is used in describing the equity reorganization receivership, this procedure may still be used, but it has been largely superseded by the new statutory bankruptcy reorganization. See p. 384 , infre.

${ }^{21} 3$ Srar. rogr (19xi).
} 
court in which the primary proceedings have been instituted to control the operation of the entire railroad system.

The receivership proceedings were instituted through filing a petition for appointment of a receiver in the federal district court of the district in which the carrier's chief operating offices and a material part of its line were located. ${ }^{12}$ Similar bills were simultaneously filed, as was noted above, in all other district courts in which the debtor had important properties. The bills alleged, among other things, that the defendant was indebted to the plaintiff and was insolvent; that there were other creditors whose debts had matured and which the company was unable to pay; and that it would be dismembered through attachment and execution if a receiver was not appointed and its assets administered. The allegations of these bills were admitted by the debtor who joined in the prayer for the appointment of a receiver. Courts of the ancillary proceedings usually appointed as their receivers the same individuals named as receivers by the court of the primary proceedings. It was customary for the court to name two or more receivers, one of whom was usually an officer of the debtor experienced with its operations.

Shortly after the receivership proceedings were instituted, the mortgage trustees under defaulted mortgages obtained the court's permission to commence foreclosure proceedings. The foreclosure bill, in connection with which a receiver of the mortgaged property was requested, was filed with the receivership court sitting in the district within which the property was located. The receivership was extended to the mortgage foreclosure suit by court order, and the persons named as receivers in the original receivership bill were usually named receivers in the foreclosure proceedings.

When the foregoing steps had been taken, the reorganization proceedings may be said to have been completely launched. The long-range objective thereof, namely, the foreclosure of the debtor's property and sale to the new company, would usually, however, be several long and weary years away. In the meantime, a plan of reorganization had to be devised and adequate support obtained for it. The so-called protective or reorganization committee system performed this function.

\section{The Protective Committee System in Equity Reorganization}

Since railroad properties are so extensive and valuable that outside bidders are almost unknown at their foreclosure, the investors in the old company were compelled to get together and acquire the property themselves if they hoped to salvage any portion of their original investment. This they almost invariably did by forming a new company to take over the properties. And if the new company was to be financially sound, it was necessary that its fixed charges should be materially lower than those of its predecessor. The situation, therefore, required investors of the old company to accept obligations of the new having a lesser face amount or reduced interest, or perhaps to take all or some portion of their claims against the former in stock or other contingent securities of the new company. Other classes of creditors

${ }^{22}$ Farmers' Laan \& Trust Co. v. Northern Pacific R. Co., 72 Fed. 26 (1896). 
and stockholders, if they were permitted to participate in the reorganization at all, were required to make similar sacrifices. The complicated adjustments incident to such a re-shuffling of corporate interests obviously could not be worked out on 2 town mieeting basis, even if it had been possible to bring together at one place thousands of scattered creditor and equity interests. The protective committee system was designed to permit the accomplishment of these re-adjustments.

Protective committees were self-constituted groups, formed to represent the various creditor and stock interests of the insolvent carrier. Usually each creditor or equity class had its separate committee. The common-stock committee was likely to be sponsored and dominated by the management of the debtor; bondholder committees by the investment bankers originally selling the issues to the public. ${ }^{13}$ Rival committees, backed by diverse interests, frequently put in an appearance. Creditors and stockholders were solicited by their respective committees to deposit their securi ties with the committees pursuant to the terms of what is known as a deposit agreement. This agreement conferred broad powers on the committees and authorized them, among other things, to take all necessary steps to protect the depositors in connection with the reorganization proceedings and in the furtherance and development of a plan of reorganization. ${ }^{14}$ The plan of reorganization was, at least in theory, the result of prolonged negotiations carried on among the various committzes. No mathematical basis existed for the determination of what interests particular classes of creditors or stockholders of the insolvent debtor should have in the reorganized company. The treatment accorded individual classes depended on such factors as the strength of their claims, the ability of the committees representing them, and the integrity with which their interests were protected.

A key problem facing protective committees was that of raising sufficient money to make reorganization possible. These funds were usually provided through the adoption of a reorganization plan calling for the sale of new first-mortgage bonds to a banking syndicate and by levying a so-called "assessment" on the junior equity or creditor interests of the old company. Under the assessment plan the junior interests were permitted to obtain securities in the new company only upon payment of a designated amount of money. Because of the uncertainty involved in the raising of needed money in this way, the reorganization plans almost invariably provided for an underwriting of the proposed sale of securities to the junior interests.

After a plan of reorganization was agreed upon by the committees dominating the reorganization, their depositors were notified that a copy of the proposed plan had been lodged at a designated place where it might be examined by them. Those who were dissatisfied were permitted to withdraw their securities upon payment of their pro-rated share of the committee expenses. Provision was usually made that

\footnotetext{
21 Dewing, op. cit. supre note 1 , at 1104 .

${ }^{16}$ For a more detailed description of deposit agreements and related problems, see Cravath, The Reorganizarion of Corpotations in Some Legnz Phases of Corporate Financing, Reorganization and Regulat7on (1917) 153,162 et seq.
} 
failure of a depositor to withdraw his securities within a stipulated period constituted an acceptance of the proposed plan.

\section{Foreclosure and Sale of the Property and Consummation of the Plan}

After the dominating protective committees had decided that their plan had the support necessary to make a reorganization possible, a decree of foreclosure of the debtor's property was sought. In connection with the foreclosure proceedings a hearing was held in which the court set a price known as the upset price below which it would not permit the property to be sold. This price was set in order to prevent creditors and stockholders supporting the reorganization plan from acquiring the property at an unconscionably low figure. This was a frank recognition of the fact that in most cases involving large railroad properties the latter group was the only possible purchaser. ${ }^{15}$

At the sale on foreclosure the property was bid in by representatives of creditors and stockholders of the old company, known as the purchase committee, and thereafter it was transferred to a new corporation which had been formed to take it over. After 1920 it was necessary for the new company to receive the Interstate Commerce Commission's approval of the securities it proposed to issue. ${ }^{16}$ Securities in the new company were then delivered to those participating in the reorganization plan on the basis therein provided. Those refusing to acquiesce in the reorganization plan were paid in cash their pro rata share, if any, of the price for which the property was sold on foreclosure.

The transfer of the railsoad properties to the new company terminated the reorganization proceedings for most practical purposes, and if no doctrines of reorganization law had been violated, the new company took the property of the old, free of all the latter's debts which were junior to the foreclosed mortgages. The reorganized company started its life subject only to the undisturbed mortgages of the old company and to the obligations which it assumed under the reorganization plan.

\section{The Doctrine of Northern Pacific Railway v. Boyd}

The Boyd ${ }^{17}$ case established, or at least made clear, an important limitation on the rights of stockholders to participate in reorganizations. Prior to this case, it had been assumed that if mortgaged railroad property was foreclosed and sold for less than the amount of the mortgage, purchasing bondholders were privileged to deal with the acquired property as they saw fit. This notion, however, received a rude jolt in the Boyd case. In this case the Northern Pacific Railroad had been reorganized through the foreclosure and sale of its property to the Northern Pacific Rail-

\footnotetext{
15 The advantage in favor of those supporting the plan having overwhelming support is easily perceived. If a corner lot, having a $\$ 5,000$ mortgage thereon, is sold on foreclosure for $\$ 3,000$ vad is bid in by the mortgagee, the latter is entitled to credit the amount of the debe on the price which he paid for the property. Hence, he merely has to put up enough money in such circumstances to pay the expensea of foreclosure sale. Similarly a purchase committee representing $95 \%$ of the bondholders are entitled to a credit of $95 \%$ of the sale price of the property which they are purchasing. The holders of the remaining $5 \%$ of the securities would have only a $5 \%$ credit. This large differential can usually be counted upon to prevent the minorities from effectively bidding at foreclosure sales.

10 4 STAT. 494 (1920). Ir 228 U. S. 482 (1913).
} 
way Company. The bondholders' reorganization plan provided that stockholders of the old company might obtain an interest in the new by making a specified cash payment. No provision was made for participation in the plan for general unsecured creditors of the old company. Ten years after the reorganization had been completed, Boyd, an unsecured and unpaid creditor of the old company, brought suit against the reorganized company. He asserted that since no provision had been made for his claim, the transfer of the assets of the old company was fraudulent, and that consequently the transferee company was liable for the debt of its predecessor. The claim of Boyd was sustained, and a decree was entered making his claim a lien on the property of the reorganized company. The rationale of the decision was that bondholders, who might have purchased the property for themselves alone, could not permit stockholders to obtain an interest in the new company pursuant to an arrangement made before the sale, without also giving every creditor of the old the privilege of participating in the reorganization on a fair and equitable basis. The Boyd decision was variously described as the demon incarnate and as a perpetual spectre across the path of corporate reorganization. A profound fear existed that the Supreme Court's requirement of a fair and equitable plan of reorganization was such a vague and uncertain guide that those creditors who had not become parties to the reorganization would be able to contest the fairness of the reorganization many years after it had been consummated and to hold the new company liable for the debts of its predecessor where the judgment returned was that the reorganization plan was unfair as to them. Such a possibility was obviously a serious threat to the efficacy of the reorganization process, as the estimate of the fairness of the plan years after the event would all too likely be influenced by hindsight rather than foresight.

Steps were immediately taken, however, to plug the reorganization hole which had been revealed by the Boyd case. 18 The expedient adopted was to have the fairness of the reorganization plan litigated in the foreclosure proceedings. This was done by inserting in the decree of foreclosure a provision that the sale would not be confirmed by the court unless, after hearing, it was satisfied that a fair and timely offer of participation had been made to all creditors of the old company. Provision was also made for notifying creditors of the terms of the decree, of the filing of the reorganization plan, and of the hearing to be held thereon. The result of the new procedure was that all creditors of the old company, whether or not they were parties to the reorganization proceedings, became bound by the terms of the plan upon confirmation of the sale of the properties. In the words of one writer, the doctrine of the Boyd case became reasonably domesticated. .

\section{Criticism of the Equity Reorganization Process}

Dissatisfaction with various aspects of the equity reorganization scheme mounted with the years. The cumulative effect of a wasteful system of ancillary proceedings, the necessity for the essentially ritualistic sale on foreclosure of the insolvent's

\footnotetext{
${ }^{18}$ See Swaine, Reorganization of Corporations: Certain Developments of the Last Decade in Sone Leant. Phases of Corporate Financing, Reorganization and Regulation (1931) 133, 142 et seq.
} 
property, the fees exacted by the numerous protective committees, rcorganization managers, mortgage trustees, receivers, and their.counsel, contributed to make reorganization costs exorbitant, if not scandalous. ${ }^{19}$ Reorganizations were dominated all too frequently by investment banking interests who, through their influence over protective committees, were enabled to shape reorganization plans to their own ends.20 Protective committees, assuming to represent various classes of securityholders, often had interests which conflicted with those of their depositors.21 Too frequently reorganizations were financially unsound. ${ }^{22}$ Fixed charges often were not adequately reduced, ${ }^{23}$ and it was not uncommon for a reorganized company" to emerge from reorganization with a larger total capitalization than that of its predecessor. ${ }^{24}$ Nor did the authority of the ICC over the issuance of securities result in material improvement of the financial structures of the reorganized companies. The Commission's control was brought to bear so late in the proceedings that it usually gave its reluctant approval to unsound capital structures in order to avoid the costs of prolonged receivership. ${ }^{25}$ Reorganization plans, too, were frequently unfair. The judges were too busy carefully to examine the plans proposed, ${ }^{26}$ and they, like the ICC, were brought into the proceedings at the very end of the process, at a time when they were reluctant to upset the result of years of labor.

The rumblings of discontent over the equity system reached a climax in the last days of the Hoover regime, when a dangerously large number of railroads were either already in receivership or on the verge. Congress then enacted under its federal bankruptcy power a comprehensive system of statutory reorganization for the railroads of the country.

\section{THE Statutory Schear}

\section{Institution of Proceedings and Control of the Properties}

The new reorganization statute, known as Section 77 of the Bankruptcy Act, ${ }^{27}$ provided that interstate railroads which were insolvent or unable to meet their debts as they matured, might be reorganized in the federal bankruptcy courts. ${ }^{28}$ The rehabilitation proceedings could be instituted through filing a petition requesting reorganization in a federal bankruptcy court by the carrier itself, or, where approval of the ICC was first obtained, by creditors having $5 \%$ of its total outstanding indebtedness (\$77a). On approval of the petition the debtor might be left in possession of its property, or one or more trustees might be appointed to take over its operation

10 See testimony of Commissioner Joseph B. Eastman, Hearings before Committee on the Judiciary on H. $R$. 6429, 74th Cong., 1st Sess. (1935) 14 .

20 Report to Securities and Exchange Commission on the Study and Investication op the Work, Activities, Personnel and Functions of Protective and Reorganization Committee (1937) 863 et seq.

21 Report to Securities and Exchange Conmission, supro note 20, 2t 863 at seq.

22 Moulton et al., The American Transportation Problem (1933) 321.

s2 3 A Sharfman, The Interstate Commerce Commission (1935) 584.

26 Dewing, op. cit. supra note 1 , at 1159.

${ }^{28}$ Moultow et al., op. cit. supra note 22, at $350,356$.

${ }^{20}$ Frank, Some Realistic Reflections on Some Aspects of Corporate Reorganization (1933) Ig Va. L. Rev. 54x, 565. s1 47 Stat. 1474 (1933).

"The statute did not abolish the equity receivership. See $577 k$. 
(\$77c). The provision allowing the debtor to continue in possession where no trustee was appointed was an innovation in reorganization practice. It was based on the theory that financial misfortunes occasioning reorganization may be due neither to inefficiency nor to culpability of the debtor's management, and that in such circumstances the properties should be left in the hands of those familiar with its operation. Where trustees were appointed, however, they were to be selected from a panel of standing trustees, designated in adyance by the ICC $(\$ 77 \mathrm{c})$.

Once the initiatory proceedings received the court's blessing, ${ }^{29}$ the debtor or trustees, as the case might be, were vested with title to the property and authority to operate the business, subject, however, to the control of the judge and of the ICC, as provided in the Interstate Commerce Act $(\$ 77 c)$. The reorganization court was likewise vested with exclusive jurisdiction over all of the property of the debtor, even though portions might lie in other judicial districts $(\$ 77 \mathrm{a})$, thereby eliminating the necessity for expensive and relatively inefficient ancillary proceedings characteristic of the equity reorganization process. Appropriate provisions also operated to stay creditor actions affecting the debtor's property $(\$ 77)$. Creditors and stockholders were required to file their claims $(\$ 77 c(5))$ and the judge was ordered to classify them for voting on the reorganization plan later to be formulated ( $\$ 77 c(5))$.

\section{Procedure for Formulation of Reorganization Plans}

The basic objective of the new statute was to provide machinery which would avoid the undue delay and inordinate costs of the equity reorganization process and at the same time assure the development of fair, equitable, and financially sound reorganization plans by means of administrative and judicial safeguards which were lacking or inadequate in the equity reorganization process. The ICC was required to hold public hearings after due notice, at which creditors or stockholders were entitled to be heard on proposed reorganization plans $(\$ 77 c(9))$ before they could be finally asked to accept any reorganization plan $(\$ 77 \mathrm{~d})$. At these hearings the debtor was directed to present its proposed plan, and trustees of the debtor and persons representing not less than $10 \%$ in amount of the claims of any class of creditors might likewise propose reorganization plans $(\$ 77 \mathrm{~d})$. Following a hearing on proposed plans, the Commission was directed to render a report recommending a plan of reorganization which might differ from any plan which had been submitted to it $(\$ 7 \gamma d)$. No plan might become effective without the prior approval of the Commission ( $\$ 77 \mathrm{~d}, \mathrm{e}, \mathrm{f})$, nor could one be approved by the Commission or the court unless it was equitable, did not discriminate unfairly in favor of any class of creditors or stockholders, was financially feasible, and in the public interest $(\$ 77 \mathrm{~d}, \mathrm{f}, \mathrm{g})$. The influence of the principle of equity reorganizations, that the reorganization plan shall be fair and equitable, is to be clearly discerned in these provisions. ${ }^{30}$

\footnotetext{
21 The judge was required to approve the petition if be was satisfied that it was filed in good faith and complied with the technical requirements of the Act. $\$ 772$.

20 The words "fair and equitable" as used in the statute are words of art which have acquired a fixed meaning through judicial interpretation in the field of equity receivership reorganization. Cf. Case v. Los Angeles Lumber Co., 308 U. S. 106, 115 (1939).
} 
Provisions Relating to Creditor and Stockholder Acceptance of Reorganization Plans

A great practical difficulty of the equity reorganization process lay in the necessity of having available sufficient cash to pay reorganization expenses, provide new capital, and satisfy the claims of the unpredictable number of creditors who might refuse to participate in the reorganization. ${ }^{31}$ Accordingly it was felt that the reorganization process should be democratized, so that creditor and stockholder minorities would be bound by majority decision. Section 77 therefore provided that a plan of securities readjustment which was approved by the ICC, confirmed by the court, and accepted by a two-thirds majority in amount of any class of creditors or stockholders, should become binding upon the remainder of the class $(\$ 77 e, \mathrm{~g}, \mathrm{~h})$.

Congress recognized, however, that it was unlikely that the acquiescence of a majority of all classes of creditors and stockholders could be obtained in all situations. Obstructionist tactics on the part of dissenting classes, not to mention the bona fide dissent of investors who would feel that they were being unjustly dealt with, appeared inevitable. In order to prevent dissenting classes of either stockholders or creditors from blocking reorganization unless their demands were met-demands which might easily become extortionate-steam-roller provisions were included in the statute which made their acquiescence unnecessary in certain circumstances $(\$ 77 e)$. The consent of any class or classes of creditors or stockholders was dispensed with where (I) a plan of reorganization provided for the payment in cash, at the claimant's option, either of the value of his claim or the value of the securities allocated under the plan to his interest in the old company, or (2) where provision was made in the reorganization plan for a sale of the debtor's property to the reorganized company at a price not less than that to be fixed by the ICC, called the upset price ( $\$ 77 g, e)$. Where reorganization was based on sale at an upset price, nonacquiescing classes of creditors and stockholders were entitled to cash payment of such proportion of the sale price as was allocable to their interests. ${ }^{32}$ Shareholder acquiescence was likewise dispensed with under the steam-roller provisions where it was established that their equity in the enterprise was gone $(\$ 779, \mathrm{e}) .^{83}$ And bondholder acceptance was made unnecessary where the reorganization plan provided for a sale of the debtor's property subject to their liens $(\$ 77 \mathrm{~g})$.

\section{Proceedings for Confirmation and Consummation of Reorganization Plans}

A plan of reorganization which was approved by the Interstate Commerce Commission and accepted by the requisite majorities of creditors and stockholders, unless that consent was made unnecessary, was required to be certified to the court by the

\footnotetext{
${ }^{21}$ See Swaine, Corporate Rearganization under the Federal Bankripley Power (1933) 19 VA. L. Rev. $317,326$.

"3s The upset-price provision, it might be noted, was borrowed from the equity reorganization process where it was habitually set so low as to have the effect of driving dissatisfied minorities into reorganization plans. Weiner, Conflicting Functions of the Upset Price in a Corporate Reorganization (1927) 27 Cor. L. REv. 132, 137, n. 28.

as Their consent could also be dispensed with where their interests were not to be adversely affected by the plan, or where by authorized corporate action the plan bad been accepted by their company and they were bound by its acceptance. $577 \mathrm{e}$
} 
Commission, together with the latter's report of the proceedings ( $\$ 77 f)$. After such certification, the judge held public hearings on the approved plan, at which time he considered the stockholders' and creditors' objections, and confirmed the plan if it complied with the requirements of the Act (\$77g). The provisions for the court hearings were undoubtedly introduced to minimize the chance of a successful challenge of the statute's validity on constitutional grounds. It is to be doubted, though, that the draftsmen of the Act expected that the judges would, except possibly on rare occasions, concern themselves with a detailed examination of reorganization plans theretofore approved, and perhaps formulated, by the ICC after the full hearings required by the Act. $^{34}$

A plan of reorganization which was confirmed by the court was made binding on the debtor and on all of its creditors and stockholders $(\$ z 7 \mathrm{~h})$. The property of the insolvent was thereafter transferred to the reorganized company which received it free from all obligations of the old enterprise, save as otherwise provided in the reorganization plan (77j). The costly and essentially ritualistic sale on foreclosure was eliminated through a provision permitting the debtor's property to be retained by it or transferred to another corporation without foreclosure (\$77j).

\section{The Protective Committee and the New Legislation}

Under the new legislation the protective committee system was shorn of a considerable amount of the power which it possessed in the equity reorganization. Court and administrative controls over the formulation of reorganization plans were introduced at a sufficiently early stage of the reorganization process to make their existence effective $(\$ \$ 77 \mathrm{~d}, \mathrm{e} ; \mathrm{f})$. Then, too, the committee system was weakened by the referendum set-up of the statute. The ICC was required to refer its recommended plan directly to stockholders and creditors $(\$ 77 d) .^{35}$ If securities had been deposited with a protective committee before the Commission's recommended plan was announced, the committee apparently was permitted to vote on deposited securities only in the event it was authorized to do so by a new authority executed after promulgation of the plan ( $\$ 77 \mathrm{e}) .^{36}$ This provision, in the opinion of the writer, was introduced to prevent voting power from falling into the hands of protective committees through sheer inertia on the part of depositors, and because it was undoubtedly thought that the prestige of plans recommended by the ICC would be sufficient to influence investors to accept them even though they should be opposed by such committees. The new legislation, however, made no attempt to regulate the protective committee system with respect to possible unfair solicitation practices, the use of one-sided deposit agreements, and its failure to provide disinterested depositor representation. ${ }^{37}$

"This view is supported by the fact that court consideration of the plan was not bronght to bear until after there had been a submission to creditor and stock interests. 577 , .f.

"It might also, if it saw fit, submit any other plan which had been filed in the proceedings. 377 .

"For a contrary point of view, soe Rogers and Groom, Reorganization of Railroad Corporations undes Section 77 of the Bankruptcy Act (1933) 33 CoL. L. REv. 57t, 6ro.

- ${ }^{27}$ The Securities Act of 2933 (48 STAT. 74) applied to certificates of deposit issued by protective committees. It did not, though, attempt to regulate the terms of such agreements or the personnel of the committees. Committees were, however, compelled to disclose impartant information, such as their past 


\section{Miscellaneous Provisions}

Limitations of space prevent more than a brief reference to some miscellaneous provisions for reorganization control which were introduced by the new legislation. Expenses to be paid from the estate of the debtor, including compensation to trustees and their counsel, to reorganization committees, managers, and other creditor and stockholder representatives, were required to be fixed by the court within maximum limits prescribed by the ICC $\left(\$_{777} c(8)\right)$. It was thought that these limitations did not prevent protective comrnittees from making private arrangements with their depositors concerning their remuneration and expenses. ${ }^{38}$ Claims for personal injury to employees were made preferred claims, outranking even first mortgages $\left(\$ 77^{5}\right)$. Judges and trustees were prohibited from recognizing "yellow dog" contracts ( $577 \mathrm{P}$ ), from promoting company unions ( $\$ 77 \mathrm{P})$ or, with certain restrictions, from changing employees' wages or working conditions $\left(\$ 77^{\circ}\right)$.

\section{THE AMENDMENTS OF 1935}

\section{General Scheme of the Amended Act}

The experience with Section 77 indicated the desirability of further reorganization reform and in 1935 the Federal Coordinator of Transportation recommended a comprehensive revision of the Act. In the same year, after extensive hearings, Congress enacted the proposed legislation in general accordance with the Coordinator's recommendations.

Although the original Act was overhauled from stem to stern-scarcely a sentence of the original Act remaining unchanged-its underlying conception was retained. Proceedings under the new Act may be instituted by a carrier in the same way and are subject to the same conditions $\left(\$ 77^{\mathrm{a}}\right)$. Creditors, however, may now institute proceedings without the prior approval of the ICC $(\$ 77 a) .^{30}$ The appointment of trustees for the debtor is required under the amended Act $(\$ 77 \mathrm{C}),{ }^{10}$ the trustees to be selected, not from a panel as before, but by the judges subject to the approval of the Commission. ${ }^{11}$ The Commission retains its key position with respect to the formulation of and veto over reorganization plans (\$77d) and control over reorganization expenses $(\$ 77 c(12))$. In order to expedite reorganizations where that is desirable, the debtor is directed to present a proposed reorganization plan within six months after the approval of the reorganizalion petition (\$77d). ${ }^{2}$ Permission to file

affiliations, the circumstances surrounding their organization, etc. See SEC, Form D-I. They could,

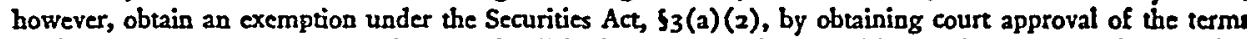
of their deposit agreement in advance of solicitation. Under the Securities Exchange Act of 1934 (48 STAT. 88. ) committees were required to file a listing application in conformance with that Act, if their certificates of deposit were to be listed on 2 national security exchange.

${ }^{28}$ Rogers and Groom, supra note 36, at 587 .

" This change was made because the original Act provided no standard for determining the circum: stances in which such approval should be given or withheld.

"An exception was made with respect to small carriers whose annual operating revenues were less than $\$ 1,000,000$ a year.

"One reason for this change was the diffculty experienced by the Commission located in Washington in selecting for the panel suitable persons living in other parts of the country.

"2 This period may be extended, for cause shown, for intervals not exceeding six month each. 377 . 
proposed plans is extended to stockholders having not less than $10 \%$ of any class of stock, and to other interested parties who obtain the consent of the Commission $(\$ 77 d)$. The order of procedure for reference on reorganization plans is greatly improved. ${ }^{48}$ The amended Act provides that a proposed reorganization plan shall be certified to the court after approval by the Commission and before it is submitted to creditors and stockholders $(\$ 77 \mathrm{~d})$. If court approval is withheld, the plan may be merely returned to the Commission for further consideration (\$77e). Under the original scheme a costly and time-consuming submission to creditors and stockholders would have been rendered useless where the court refused to approve the submitted plan.

The amended Act retains the provisions for majority creditor and stockholder control of reorganization (\$77e). Continued also, although amended in certain respects, are the steam-roller provisions permitting the effectuation of reorganizations over the objections of non-acquiescing classes of creditors and stockholders (\$77e). The changes made in this connection, together with the new so-called "cram-down" provisions of the amended Act, will be discussed later. And, as under the original Act, the reorganized company obtains the properties of the debtor free from all old debts save as otherwise provided in the confirmed reorganization plan ( $\$ 77 f)$.

\section{Defects in the Valuation and Upset Price Provisions of the Original Statute}

The steam-roller provisions of the original statute, which were designed to permit reorganization over the objections of dissenting classes of creditors or stockholders, were key provisions of the legislation $(\$ 77 \mathrm{e})$. Unless they possessed a high degree of practicability, the new reorganization technique was likely to be ineffective in an important number of instances, because reorganization plans proposed thereunder probably would not be acceptable to all classes of creditors and stockholders. Under one of the steam-roller provisions the consent of classes was dispensed with where the reorganization plan provided for a sale of the debtor's property at not less than a fair upset price (\$77g). This provision was thought to be defective and of little practical utility. Both courts and scholars were in wide disagreement concerning the proper basis for determining the upset price.44 The chaotic condition of the law and the uncertainty concerning the principles applicable to upset-price determination were regarded as making it unsound to rely on the upset-price technique as a principal means of implementing reorganization. The jumbled state of the law, too, was all too likely to encourage costly and undesirable obstructive litigation.

The other important provision dispensing with investor acquiescence was based on the payment in cash of the value, if any, of the interest of dissenting classes. Shareholder consent was made unnecessary both where the company was found to be insolvent $(\$ 77 \mathrm{e})$, i.e., where the value of its assets was less than the aggregate of its debts, and where the reorganization plan provided for appraisal of their interests

\footnotetext{
42 For procedure under original statute, see pp. 385-387, supra.

"Bonbright and Bergerman, Two Rival Theories of Priority Rights of Security Holders in a Corporate Reorganization (1928) 28 COL L. Rev. 127.
} 
and for cash payment of the value thereof $(\$ 77 g)$. The latter provisions aleo applied to dissenting classes of corporate creditors (\$77g). These provisions for eliminating creditor and stockholder acquiescence were regarded as unsatisfactory because it was feared that, in the absence of applicable legislation, principles of valuation as applied in rate-making proceedings might be invoked. ${ }^{45}$ The difficulties inherent in the valuation of great railroad properties on the basis of rate-making principles, together with the enormous costs and intolerable delays accompanying their application, would have made a dead letter of the appraisal provisions. With the upset-price provisions impracticable and the appraisal provisions ineffective, the likelihood seemed great that the Act would fail as an effective reorganization vehicle. Accordingly a highly important innovation was included in the amended legislation. The method of approach was to make the appraisal provisions workable. This was done through incorporation of a comprehensive formula specifying the basis upon which valuations were to be made. In the formula the emphasis was shifted from the factors giving rise to the difficulties in rate-making valuations to the ultimate economic basis of all industrial plant valuation-the earning power of the properties $(577 \mathrm{e})$.

\section{The "Cram-Down" Provisions of the 1935 Amendments}

Under the amended Act a plan of securities readjustment may become binding on dissenting classes of creditors or stockholders, even though they are offered no alternative of cash payment for their interests in the old company (577e). These so-called "cram-down" provisions may be invoked, however, only where the court finds, after hearing, that the reorganization plan makes adequate provision for the dissenters' interests and that their rejection of the approved scheme of securities readjustment is not reasonably justified. It was expected that these provisions would be used only in extraordinary situations. They were added because it was thought that particular. reorganizations might be seriously impeded or prevented through inability to raise the amount of cash which would otherwise be necessary. While these provisions provoked charges of unconstitutionality, ${ }^{40}$ they were defended on the seemingly sound basis that the accomplishment of fair and sound reorganizations, which are required both in the public and private interest, would be rendered difficult if not impossible if cash payment to dissenting classes were an invariable requirement ${ }^{47}$

\section{Amendments Pertaining to Ciassification of Creditors and Stockholders}

As originally enacted, Section 77 was thought to be defective in that it elevated dissenting groups to a position of undeserved strength. It required a division of creditors and stockholders into separate classes according to the nature of their respective interests $(\$ 77 \mathrm{C}(5))$. This provision was interpreted by the courts in such a

\footnotetext{
"In the Hearings before the Committee on Judiciary on H. R. 6249, 74th Cong., Ist Sess. (1935) 152, 215 et seq., 291 et seq., the equity interest vigorously advanced this point of riew.

${ }^{\circ 0}$ Friendly, Amendment of the Railroad Reorganization Act (1936) 36 CoL. L. REv. 2\%, 32.

17 For a more claborate argument supporting the constitutionality of these provisions, cee Craven and Fullex, The 1935 Amendments of the Railroad Bankmptcy Act (1936) 49 Harv. L. Rsv. 1254 .
} 
way as to encourage proliferation of classes, which naturally resulted in an undue strengthening of minority groups. ${ }^{48}$ The opportunities of such groups for quick and aggressive opposition were greater where individual classes consisted of a single or perhaps a few creditors, than would have been true if they had been submerged in the membership of a large class. The amended statute was designed to discourage such over-classification.

\section{The Protective Committee and the Amended Act}

The amended Act envisaged an increase in the influence of the protective committee system. Under its terms proposed plans of reorganization may be submitted directly to protective committees as representatives for security depositors ( $\$ 77 \mathrm{e}, \mathrm{p}$ ). The relaxing of the stringency of the old Act in this respect, however, was more than compensated for by the introduction of new and highly important provisions subjecting such committees to strict regulation ( $\$ 77 \mathrm{p})$. It was made unlawful for any person to solicit proxies or authority to represent creditor or stockholder interests in connection with pending reorganization proceedings without first obtaining the approval of the ICC. In passing on applications under this section, the Commission considers, among other things, such relevant matters as the manner of proposed solicitation, the rate of compensation to be charged by the applicant, his business connections and other committee interests which might be inconsistent with disinterested representation, and the terms of the proxy authorization or deposit agreement under which the applicant proposes to act. ${ }^{10}$

\section{Miscellaneous Provisions under the Amended Act}

A number of particularly important miscellaneous changes in the original Act should be mentioned in passing. Section 77 was interpreted by the Supreme Court as requiring prompt reorganization, even though conditions were such that a slow tempo might be in the better interests of all concerned. ${ }^{50}$ Accordingly the statute was amended to ease the requirement of prompt reorganization and to permit court retention of the proceedings so long as there was not an undue delay (\$77g).

The provision permitting the allowance of compensation $(\$ 77 c(8))$ to protective committees and reorganization managers out of the debtor's estate was eliminated. Under the amended Act such committees might obtain from the estate of the debtor only their actual and reasonable expense, including reasonable attorney's fees $(\$ 77 c(12)) .01$ Other amendments permit mortgage trustees to file claims on behalf of bondholders who have failed to act in their own behalf $(\$ 77 c(7))$. The original Act required the compilation from the records of the debtor of a list of all its

\footnotetext{
"In the pending Missouri Pacifie case, the stock and creditor interests were originally classified into 72 different groups.

"See Fennell, Protective Commiltees and Deposit Agreements in Railroad Reorganization (1939) 49 Yale L. J. 224, 230 et seq.; Fennell, The Protection of Security-Holders Interests under Section 77. infra p. 477 et seg.

"Contineneal Illinois National Bank \& Trust Co. v. Chicago Pacific Railway, 294 U. S. 648 (r935).

"2 The wisdom of this change is not clear, but, at the time the bill was enacted, Congressional disapproval of committee charges was too great to permit an objective approach to the problem.
} 
creditors and stockholders and this list was open to inspection by designated parties in interest $(\$ 77 c(9))$. The utility of this provision was limited by the fact that bondholder lists were likely to be in the hands of persons other than the debtor, such as the paying agents under the debtor's mortgages, for example. Accordingly the statute was amended to provide that any person having such a list should be under the duty to supply it $(\$ 77 c(5))$.

The railroad reorganization process, as it developed from the earliest stages, has been characterized by a constant endeavor on the part of courts and lawyers to adjust, adapt and evolve legal machinery which would adequately cope with the enormously difficult problems of the insolvent carrier. The progress which was made was slow and halting for many years, for shaping antiquated legal machinery to meet the new needs was a formidable task. Had legislative aid been forthcoming at the outset, the problem would have been greatly simplified. When it did come, though after many years, a long step was made toward the goal of sound, fair and reasonably inexpensive railroad reorganizations. Experience with the statute, however, revealed important deficiencies. This was hardly a surprise, as perfection in new legislation concerned with such complex problems was hardly to be expected. Extensive amendments attacking these deficiencies constituic $a$ further stride toward the reorganization goal. Now that the barricade of legislative indifference has been shattered, it is to be hoped that such shortcomings as may have been revealed in the existing legislation will receive the prompt Congressional attention required by the importance to the country of a sound system of railroad transportation. 